\title{
The influence of hydrological regimes on sex ratios and spatial segregation of the sexes in two dioecious riparian shrub species in northern Sweden
}

Francine M. R. Hughes, Mats Johansson, Shaojun Xiong, Elisabet Carlborg, Dawn Hawkins, Magnus Svedmark, Adrian Hayes, Alexander Goodall, Keith S. Richards and Christer Nilsson

F.M.R. Hughes and D. Hawkins

Animal and Environment Research Group, Department of Life Sciences, Anglia Ruskin University, East Road, Cambridge, CB1 1PT, UK;

M. Johansson, S. Xiong, E. Carlborg, M. Svedmark and C. Nilsson

Landscape Ecology Group, Uminova Science Park, Department of Ecology and Environmental Science, Umeå University, SE-901 87 Umeå, Sweden;

A. Hayes and K.S. Richards

Department of Geography, University of Cambridge, Downing Place, Cambridge CB2 3EN, $U K$;

A. Goodall

University of Cambridge Botanic Garden, Cory Lodge, Bateman Street, Cambridge CB2 1JF, $U K$.

Corresponding author:

F.M.R. Hughes, e-mail: Francine.Hughes@anglia.ac.uk ), Tel: ++ 44 (0)845 1962607

Abbreviated title: Impacts of hydrology on riparian shrub sex ratios

Keywords: Hydrological regime $\cdot$ Regeneration niche $\cdot$ Riparian ecology $\cdot$ Salix myrsinifolia-phylicifolia $\cdot$ Sex ratios $\cdot$ Spatial segregation of sexes 


\begin{abstract}
River management practices have altered the hydrological regimes of many rivers and also altered the availability of regeneration niches for riparian species. We investigated the impact of changed hydrological regimes on the sex ratios and the Spatial Segregation of the Sexes (SSS) in the dioecious species Salix myrsinifolia Salisb.-phylicifolia L. and S. lapponum L. by studying the free-flowing Vindel River and the regulated Ume River in northern Sweden. We surveyed sex ratios of these species in 12 river reaches on the Vindel River and in 17 reaches on the Ume River. In addition we surveyed the sex and location above mean river stage of 1002 individuals across both river systems to investigate the SSS of both species. Cuttings were collected from male and female individuals of S. myrsinifolia-phylicifolia from both rivers and subjected to four different water table regimes in a greenhouse experiment to investigate growth response between the sexes. We found an $\mathrm{M} / \mathrm{F}$ sex ratio in both river systems similar to the regional norm of 0.62 for $S$. myrsinifolia-phylicifolia and of 0.42 for $S$. lapponum. We found no evidence of SSS in either the free-flowing Vindel River or the regulated Ume River. In the greenhouse experiment, hydrological regime had a significant effect on shoot and root dry weight and on root length. Significantly higher shoot dry weights were found in females than in males and significantly different shoot and root dry weights were found between cuttings taken from the two rivers. We concluded that changed hydrological regimes are likely to alter dimensions of the regeneration niche and therefore to influence sex ratios and SSS at an early successional stage, making it difficult to find clear spatial patterns once these species reach maturity and can be sexed.
\end{abstract}




\section{Introduction}

River management practices have altered the hydrological regimes of many rivers and through this mechanism have also altered the availability of regeneration niches for riparian species (Hughes 1990; Mahoney and Rood 1991). These changes are more complex to understand for dioecious species because of the possibility of male and females having different regeneration niches. In dioecious species males and females have been found to make different use of environmental resources because the timing, duration and amount of energy that they invest in reproduction are different (Leigh and Nicotra 2002; Ward et al. 2002; Ueno et al. 2006). This differential resource use can result in spatial segregation of the sexes (SSS after Bierzychudek and Eckhart 1988) which reduces intra-specific competition (Onyekwelu and Harper 1979; Waser 1984; Comtois et al. 1986; Alliende and Harper 1989; Turcotte and Houle 1997). It is also possible that intra-specific competition is a contributory cause of SSS because one sex may out-compete the other if it is better adapted to make efficient use of the available resources in a given location (Hultine et al. 2007a). The sex ratios of dioecious species will be due, at least in part, to the existence of SSS and logically, when there is a change in the availability of resources, sex ratios might also be expected to shift. This has not always been observed (Rowland and Johnson 2001), perhaps because changes in resource availability also change inter-specific competition in an area, obscuring these relationships.

Because many species in the dioecious Salicaceae family are obligate phreatophytes and live in riparian zones impacted by river management activities, willows and poplars have been particularly well studied for sex-specific responses to environmental factors. For example, a more limited photosynthetic capacity was found under drought conditions in female than male Populus cathayana Rehd in riparian zones in China (Xu et al. 2008). On the other hand no sex-specific difference in photosynthetic capacity was found in response to seasonal changes in water availability in P. angustifolia James, in Alberta, Canada (Letts et al. 2008) although Rood et al. (in press) suggest that female $P$. angustifolia are more flood-tolerant than males. Studies of growth rates in $P$. nigra L. demonstrated faster growth rates by female than male cuttings in wetter sites (Hughes et al. 2000).

Although these studies show sex-specific responses to given environmental conditions, researchers have had mixed fortunes in finding evidence of SSS in the field. There is evidence of SSS in Salix arctica Pall. in arctic Canada (Dawson and Bliss 1989) and in S. 
glauca L. in the Rocky Mountains of Colorado, US (Dudley 2006) with, in both cases, female plants more common in wetter sites and males in drier sites. Females have been found on more nutrient-rich sites than males (Bierzychudek and Eckhart 1988) and on sites with lower soil temperatures (Dawson and Bliss 1989). Other studies do not find SSS, for example Gamache and Houle (1997) studying S. planifolia in sub-arctic Canada and Ueno et al. (2007) studying $S$. sachalinensis in northern Japan. Where SSS is not evident, it is suggested by Dudley (2006) that it may be taking place through different niche properties than those measured, for example, the less visible and less easily measured use of rooting spaces.

Studies of sex ratios in the Salicaceae tend to report a female-bias in contrast to the malebiased sex ratios reported across a range of other dioecious families (Willson 1983). Much of the research conducted on northern and alpine willow species has found female-dominated sex ratios, e.g. S. arctica - 2:1 (Dawson and Bliss 1989), S. rosmarinifolia L. - 3:1, S. aurita L. - 4:1, S. caprea L. - 2:1 (Falinski 1980), S. sachalinensis - 2:1 (Ueno, Suyama and Seiwa 2007). Attributing this biased sex ratio to SSS is difficult because a range of factors may be involved including: differential mortality through preferential vole feeding on males in $S$. myrsinifolia Salisb.-phylicifolia L. (Danell et al. 1985; Elmqvist et al. 1988) though this has not been found in S. polaris Wahl. in Svalbard (Dormann and Skarpe 2002) or in S. sericea Marshall (Nichols-Orians et al. 1993); an inherent, genetically based imbalance in sex ratios (Alström-Rapaport et al. 1997; Ueno et al. 2007) and density-dependent controls (Falinski 1980). Seed sex ratios in dioecious species may play an important role in resulting sex ratios among adult plants (de Jong et al. 2002), but in many members of the Salicaceae it is not possible to know the seed sex as reliable molecular markers linked to sex determination genes have not been easy to identify (Alström-Rapaport et al. 1998; Semerikov et al. 2003).

Unisexual or close to single-sexed Salicaceae populations have also been reported and are attributed to either vegetative spread of parental clones (Shafroth et al. 1994), or to human interference by planting (Tabbush 1996). Yet other studies report 1:1 sex ratios in all environments for some species, for example, Kaul and Kaul (1984) for P. deltoides Bartr. It is possible that where there is no bias in the sex ratio, males and females of a species might respond to prevailing environmental conditions by differential production of pollen and ovules (Niesenbaum 1992) or changing flowering sex ratios (Ueno et al. 2007). 
In river systems dominated by members of the Salicaceae, it might be expected that, if the species show evidence of SSS as a result of water availability, well-watered reaches will have a different sex ratio to drought-stressed reaches and SSS might occur within reaches. SSS might be expected to correspond with elevation above water table and over time these sex ratios might shift in response to changing water and sediment inputs resulting from altered hydrological patterns such as those associated with upstream dam construction. In addition, it has been shown for P. nigra L. that a changed hydrological regime can alter its capacity for genetic movement along river systems (Imbert and Lefèvre 2003) and its balance of vegetative to sexual reproduction on the floodplain (Barsoum and Hughes 1998; Barsoum 2002) both of which would influence sex ratios over time. It is anticipated that with climate change the sex ratios of riparian dioecious species will shift with consequent impacts on evapotranspiration and subsequent streamflow (Hultine at al. 2007b).

Along rivers in northern Sweden, Salix species dominate the riparian tree and shrub vegetation. It is not known if and to what degree these species display SSS. During the last century, most large rivers in northern Sweden have been regulated for hydropower production (Dynesius and Nilsson 1994). This has led to large changes in water-table regimes in riparian habitats, and in the structure and composition of the riparian vegetation (Nilsson et al. 1991; Jansson et al. 2000). Such changes typically occur because of new sediment and water delivery patterns downstream of the dams (Nilsson et al. 1991), and changed hydraulic characteristics of riparian zones (Gurnell et al. 2008). Altered propagule dispersal patterns between upstream and downstream areas have also contributed to the changes in riparian species composition (Johansson et al. 1996; Andersson et al. 2000; Jansson et al. 2000). If willows display SSS on floodplains, it is possible that the floodplains of regulated rivers and free-flowing rivers might have different sex ratios, in response to changing hydrological, sedimentological and hydraulic conditions, though measuring appropriate niche dimensions to explain such a difference might remain difficult. The juxtaposition of a regulated and a freeflowing river in northern Sweden provided us with an excellent field experimental situation in which to test this idea.

The objective of this study was to determine the influence of environmental variation, in particular hydrological variation, on sex ratios in boreal floodplain willow species. More specifically, we wanted to test the following hypotheses: (1) riparian willows along boreal rivers in northern Sweden will show SSS in relation to hydrological gradients; (2) the sex 
ratios of willows will be different in free-flowing vs. regulated rivers; and (3) under experimental conditions, male and female willow cuttings will respond differently to a range of hydrological regimes.

\section{Methods}

\section{Study species}

Variation in sex ratios along hydrological gradients was studied in the common floodplain shrubs S. lapponum L. (Downy Willow) and S. myrsinifolia-phylicifolia (dark-leaved willow-tea-leaved willow). S. myrsinifolia-phylicifolia is a morphological intermediate between two parent sympatric species, believed to be of hybrid origin and more common than either parent in many areas around the Gulf of Bothnia (Danell et al. 1985). In the boreal zone around Umeå in northern Sweden, this species has been found to have a sex ratio of around 1:1.6 (male:female) (Danell et al. 1985; Elmqvist et al. 1988).

\section{Study sites and field methods}

To investigate any SSS in relation to hydrological variables, field studies were carried out at five sites in the free-flowing Vindel River and at six sites in the regulated Ume River in northern Sweden (Fig. 1). Dams were constructed along the Ume River at several locations during the 1950s and 1960s. Both of these rivers flow from the montane areas of Sweden to the Gulf of Bothnia, traversing similar terrain and habitats and provide a useful comparative context for studying the impacts of dam construction on riparian ecology. All sites were situated within the middle-lower reaches of the rivers and were controlled for (1) similarity in the riparian sediment (fine-grained, free-draining sands dominant); (2) consistently rising slope angle away from the river channel and (3) dense Salix populations. This resulted in sites on the Vindel River being located near to each other and sites on the Ume River being more evenly spread (Fig. 1). At each site, a transect of variable width was delineated perpendicular to the river channel, comprising all (riparian) willows below the elevation of maximum river stage-level. We set as a target a minimum sample size of 40 individuals whose sex could be determined, within each transect. Consequently transects varied in width between $15 \mathrm{~m}$ and $30 \mathrm{~m}$ and numbers of individuals found within each transect varied between 45 and 107. All individuals of the two species along each transect were registered and tagged, and their positions levelled for elevation above mean river stage, determined by matching the river stage at each transect at the time of sampling with the stage level at the 
nearest stage gauge. The elevation of an individual willow above mean river stage was considered a good surrogate for available soil moisture because of the well drained sandy sediments in the riparian zone and the uninterrupted increase in elevation of the riparian zone away from the channel edge. In total, 1030 individuals were tagged and registered in this way. Individuals were distinguished by a combination of several observational methods: general spatial separation and grouping of stems, size differences, differences in phenological development, differences in leaf and twig morphology, and in some cases differences in the occurrence of systemic parasitic fungi. Ambiguous cases were determined by following directions and connections of lateral roots and if necessary, rejected. The studies were done at peak flowering time of the willows in mid to late May in 2000 and 2001. In total 760 individuals out of the 1030 study plants could be sexed and the remaining $26 \%$ had to be removed from the data analysis. The eventual sample size of sexed individuals within a transect varied between 17 and 68 .

To compare sex ratios between the two rivers, a separate study was set up in which the aim was to sex 50 individuals of both $S$. lapponum and S. myrsinifolia-phylicifolia in each of 12 reaches in the Vindel River (600 individuals in total) and 17 reaches in the Ume River (850 individuals in total). These reaches were all separate from each other and chosen based on personal knowledge of willow-rich sites. The baseline of each reach was a line perpendicular to the river. Individuals were chosen by a systematic sampling technique. The baseline was moved along the river (still perpendicular to the river) and the first 50 individual shrubs encountered between maximum and minimum river-stage levels were counted. In some cases, several shrubs were encountered simultaneously on a transect edge which meant that some transects had more than 50 shrubs included in the analysis. In some transects, there were insufficient shrubs to add up to 50, particularly for S. lapponum and in others there were no $S$. lapponum. Using this method, the length of reach used ranged between 3 and $75 \mathrm{~m}$ in the Vindel River and between 30 and $300 \mathrm{~m}$ in the Ume River and the total numbers of shrubs included in the analyses were 1448 for S. myrsinifolia-phylicifolia and 382 for S. lapponum. All reaches were situated within the middle-lower sections of the rivers.

\section{Greenhouse experimental methods}

To examine the responses of sexes to different hydrological regimes, a greenhouse experiment was carried out during 2002. In October 2001, cuttings from previously mapped and tagged female and male individuals of S. myrsinifolia-phylicifolia (see above) were 
collected from populations in the Vindel and Ume Rivers. The sampled populations in the Vindel River covered an area of about $1000 \mathrm{~m}^{2}$ that was situated $10 \mathrm{~km}$ upstream from the confluence with the Ume River. In the Ume River, the sampled trees were located along a 60 $\mathrm{m}$ long reach, $10 \mathrm{~km}$ upstream from the confluence. Because it is not possible to sex Salix seedlings it is necessary to use cuttings from sexed adults for this type of experimental work. S. myrsinifolia-phylicifolia reproduces both vegetatively and sexually in the field so we considered cuttings a suitable mimic of field conditions. After transport to the greenhouse in the Cambridge University Botanic Garden, Cambridge, UK, the cuttings were revived, standardised in weight (all cuttings weighed between 14.5 and $17.5 \mathrm{~g}$ ), though not in length or diameter, and planted in rhizopods (Hughes et al. 1997, modified from Mahoney and Rood 1991) with soil mimicking conditions in their home habitats. The soils were created by mixing $75 \%$ gravel with $25 \%$ peat and loamy soil (this $25 \%$ consisting of three parts peat and one part loam).

Each rhizopod consisted of 16 growth tubes, $1.2 \mathrm{~m}$ in height, each filled with the soil mixture and linked to a central water well that allowed different water table regimes to be administered. Eight rhizopods were used in the experiment, with two rhizopods allocated to each of four water level treatments. Each rhizopod had up to eight male and up to seven or eight female cuttings, each in separate growth tubes. In one rhizopod of each pair one growth tube was allocated for installation of hydrological monitoring equipment. No two cuttings from the same parent tree were used in any rhizopod but a similar range of cutting provenances was present in all rhizopods. At no time during the experiment did any of the cuttings flower. In total, cuttings from ten male parent trees and nine female parent trees were used in the experiment. Of the ten males, four were from the free-flowing Vindel River and six were from the regulated Ume River; of the nine females, five were from the Vindel River and four were from the Ume River.

Temperatures in the greenhouse were held at a minimum of $16^{\circ} \mathrm{C}$ and a minimum of $16 \mathrm{~h}$ of daylight were given each day. All cuttings received an initial 2-week period with optimal growth conditions during which water tables were held at $3 \mathrm{~cm}$ below the soil surface to give sufficient soil moisture and good soil aeration. Subsequently, the rhizopods were subjected to four different hydrological regimes that were chosen to represent ranges of water-level variation and precipitation in the Vindel and Ume Rivers (Table 1). The experiment ran from January $28^{\text {th }}$ until May $7^{\text {th }}, 2002$, a total of 85 days. During the experiment, the following 
environmental measurements were made: Soil suction/pressure (measured in $\mathrm{HPa}$ ) using tensiometers, at depths of $0.3 \mathrm{~m}$ and $1.0 \mathrm{~m}$, connected to Campbell data loggers and soil, water and air temperatures using thermocouples. After harvesting in May, measurements of shoot dry weight (including stems and leaves), total root length (of the main tap root) and root dry weight divided into $10 \mathrm{~cm}$ sections (measured downwards from the base of the cutting to the tip of the root) were made. Soil was gently washed from roots to preserve as many of the fine roots as possible for measurements of root weights. At the end of the experiment soil samples were collected from two depths in one growth tube in each rhizopod and analysed for $\mathrm{pH}, \mathrm{EC}, \%$ moisture by weight, $\%$ organic matter and $\% \mathrm{CaCO}_{3}$.

\section{Data analysis}

Data on SSS from the field were analysed separately for each site (because there was no clear hydrological gradient among sites) using $t$-tests to assess whether males and females grew at significantly different elevations above mean river stage. The data were not pooled within rivers because the elevation ranges of the sampled Salix individuals varied in relation to the different frequency of attainment of given water levels above the river bed in each transect. These effects introduce significant variance into the pooled data, and it would have been impossible to suppress this variation by controlling it; such control would have required standardization for inundation frequency between sites within transects, and the necessary stage-discharge relationships are difficult to construct when remote from river gauging stations, particularly in the Ume River where transects are widely dispersed. To increase the statistical power of the tests, sequential Bonferroni-corrected confidence levels were determined (Rice 1989).

Data on sex ratios in the field are given as a male to female $(\mathrm{M} / \mathrm{F})$ ratio and significant departure from a 1:1 ratio was tested using a chi-square test. Growth data from the greenhouse experiment were analysed using the univariate GLM function in SPSS 16.0 using Type III sums of squares. Root and shoot weights and root length at harvest were treated as dependent variables. Hydrological regime (experimental water table treatments listed in Table 1), river of origin (regulated Ume River vs. free-flowing Vindel River) and sex (male vs. female) were treated as fixed factors in a fully factorial design. The analysis was first run including all two-way and the three-way interaction between these factors. Since the threeway interaction was not significant, and of no a priori interest, the analysis was repeated without the three-way interaction. $P$-values remained virtually unchanged but for reason of 
parsimony the results of this second analysis are the ones reported here (Table 4). Based on $R^{2}$ values, initial cutting diameter was used as a covariate but initial cutting weight and number of buds present on the cutting at the start of the experiment were not used as covariates. Model assumptions of linearity, homogeneity and normality were checked using plots of standardized residuals against fitted values and the covariate, Levene's Test of Equality of Error Variance and histograms of standardized residuals (Grafen and Hails 2002). LSD post hoc tests in GLM were also carried out to separately inspect the significance of water table regime, river of origin and sex on the three dependent variables, using SPSS 16.0.

\section{Results}

\section{SSS along hydrological gradients}

Following application of a Bonferroni correction, results for SSS were not significant in either river for either species of willow. However, since each transect is technically a separate data set, it is worth noting that for S. myrsinifolia-phylicifolia, significant SSS was observed on two transects in the free-flowing Vindel River but on no transects in the regulated Ume River (Table 2), while S. lapponum showed significant SSS at one site along the Vindel River but was too sparse in its distribution for data analysis in the Ume River (Table 3). Females were found at a lower average elevation than males on the three transects showing significant SSS. Looking at averages across all transects for S. myrsinifolia-phylicifolia, average elevation of all females in the Vindel River was $151.5 \mathrm{~cm}$ against $154.1 \mathrm{~cm}$ for males. Average elevation of all females in the Ume River was $102.9 \mathrm{~cm}$ against $107.3 \mathrm{~cm}$ for males. Elevational ranges for each sex were also significantly different between the two river systems with a much greater range for both females $(48.4-162 \mathrm{~cm})$ and males $(43.1-171.2 \mathrm{~cm})$ in the Ume River than in the Vindel River (127.8-170.9 cm for females; $117.9-185.4 \mathrm{~cm}$ for males) (Table 2). Looking at averages across all transects in the Vindel River for S. lapponum, females were found at a mean elevation of $100.5 \mathrm{~cm}$ while males were found at a mean elevation of 119.1 cm (Table 3).

\section{Sex ratios in free-flowing vs. regulated rivers}

Across both rivers and for both Salix species, females outnumber males (Tables 4 and 5) with average M/F ratios of 0.62 for S. myrsinifolia-phylicifolia and of 0.42 for S. lapponum. Data for S. myrsinifolia-phylicifolia showed no significant difference in overall mean sex ratios between the rivers (mean $\mathrm{M} / \mathrm{F}$ ratio $=0.61$ in the Vindel River; mean $\mathrm{M} / \mathrm{F}$ ratio $=0.62$ in the 
Ume River). In the free-flowing Vindel River, $50 \%$ of study reaches had sex ratios significantly biased towards females compared with $41 \%$ in the Ume River. The overall M/F ratio of 0.62 is consistent with a female-biased sex ratio for S. myrsinifolia-phylicifolia of 0.62 in the region as a whole (Danell et al. 1985). In S. lapponum, sex ratios were more variable, but females dominated at all sites except one (mean $\mathrm{M} / \mathrm{F}$ ratio $=0.51$ in the Vindel River; mean $\mathrm{M} / \mathrm{F}$ ratio $=0.33$ in the Ume River). Overall this species was less common than S. myrsinifolia-phylicifolia with few individuals present in the Ume River.

\section{Responses of willows to experimentally manipulated hydrological regimes}

Growth response variables of the willow cuttings were to various degrees determined by all examined factors when tested separately but none of the interaction effects were statistically significant (Table 6). The hydrological regime had a significant effect on all dependent variables (Table 7). Shoot weight was significantly higher in the fluctuating water table regime (regime 2) than in all other regimes, but root length was significantly less in this regime than in all other regimes. Root weight was significantly higher under the fluctuating water table regime than under the two regimes with fastest drawdown rates (regimes 3 and 4). The differences between regimes 3 and 4 were not significant for any of the growth factors.

Patterns in root development in each water table regime showed the greatest root lengths in the two water table regimes which declined least rapidly (regimes 1 and 4) (Fig. 2). Greatest root development in shallow soil layers occurred where water tables fluctuated (regime 2) but, on average, stayed nearer the surface than in the other three regimes (Fig. 2). The pattern of water availability in the soil during the experiment is shown by the tensiometer data at depths of $0.3 \mathrm{~m}$ and $1.0 \mathrm{~m}$ under each water table regime (Fig. 3). This shows that under water table regime 1, soil moisture tension decreased gradually over the course of the experiment at both measured depths, eventually reaching similarly low values at c. $-15 \mathrm{HPa}$, indicating a negative soil matric potential and therefore soil moisture content below field capacity. Under water table regime 2, amplitude of soil moisture change was greater at the surface than at depth but average values stayed above $0 \mathrm{HPa}$ at both depths. Under water table regimes 3 and 4, soils at all depths had negative soil suctions causing stress to the plants by day 27 (regime 3) and day 43 (regime 4) of the experiment with eventual stabilisation of values c. $-15 \mathrm{HPa}$ on day 57 of the experiment accompanied by minor fluctuations resulting from the controlled weekly rainfall event. 
The river from which cuttings were taken had a significant effect on growth over the course of the experiment (Table 8). Both shoot and root weights were significantly higher in plants grown from cuttings with source trees in the free-flowing Vindel River than in those from the regulated Ume River. Root length was also greater in cuttings from the Vindel River but not statistically significant. The difference between growth of male and female cuttings across the experiment was significant for shoot weight but not for root weight or root length although female cuttings had higher values for all three growth factors than male cuttings (Table 9).

Soil analyses by the end of the experiment showed little variation between treatments for all measured soil characteristics except for $\%$ soil moisture. The lowest surface soil moisture $(0.93 \%)$ occurred in one of the tubes under water table regime 4 and the highest soil moisture $(12.0 \%)$ occurred at a depth under the fluctuating treatment (regime 2). Soil temperatures at $0.3 \mathrm{~m}$ depth during the experiment were consistent between treatments but showed increasing diurnal amplitudes and higher average values as the experiment progressed (the average moved from 15 to $19^{\circ} \mathrm{C}$ ).

\section{Discussion}

\section{SSS}

The field observations of SSS in S. lapponum and S. myrsinifolia-phylicifolia showed no significant difference between the elevation of males and females in any of the rivers when corrections were applied for multiple tests. However, females dominated at the wetter end of the hydrological gradient (as determined by elevation above mean river stage) along the few transects which individually showed significant SSS. While this is a weak result it may be indicative of low levels of SSS taking place in some locations. Assuming that elevation above $w_{\text {mean }}$ is a good indication of water availability, the observed distribution along these transects could indicate that males are more drought-tolerant and hence able to survive at higher locations and/or that females are more flood-tolerant and hence able to thrive at lower elevations. The Salicaceae literature supports the higher drought-tolerance of males (Xu et al. 2008) as well as the higher flood-tolerance of females (Rood et al. in press).

On the other hand, results for SSS are ambiguous when looked at across all transects and both species with only 7 out of 16 transects with males at higher elevations than females. In 
addition, when the results are studied for S. myrsinifolia-phylicifolia, differences in the mean elevation across the transects in each river system show little difference between males and females. There are a number of possible reasons for this result. One is that these species are obligate phreatophytes and will tend to have naturally low levels of SSS in resource-rich riparian zones (Hultine et al. 2007b) and that even these low levels of SSS are eliminated as niches on the floodplain change in response to dam construction and regulated water-level regimes. However, it may also be that measuring SSS in relation to elevation above $w_{\text {mean }}$ is not a sufficiently sensitive approach to discovering evidence for SSS and that more detailed data need to be collected on soil moisture at different seasons and elevations and on aspects of nutrient availability. The fact that $26 \%$ of willow individuals used in this study could not be sexed and used in the data analysis may have been an added complicating factor. It is also possible that SSS is occurring but underground, through the less visible partitioning of root space. In this regard, future studies might consider looking at space around individuals of each sex as an indication of root competition below ground.

In the greenhouse experiment, particular attention was paid to the partitioning of root space by the cuttings under different hydrological regimes. S. myrsinifolia-phylicifolia showed considerable flexibility in root architecture to accommodate rapidly falling or fluctuating water tables. Thus, when water tables fell rapidly, roots grew down rapidly at the expense of shoot growth but when water tables fluctuated nearer the soil surface, root development was concentrated in upper soil layers (Fig. 2). This kind of behaviour is typical of phreatophytes which track water tables with their roots and has been noted for other members of the Salicaceae family (for example, Mahoney and Rood 1991, 1992; Segelquist et al. 1993; Barsoum and Hughes 1998; Francis et al. 2005). The fluctuating water table regime (regime 2) used in the greenhouse experiment was designed to mimic the daily water level fluctuations measured between the dams in the Ume River where river stage levels can fluctuate between 0.1 and $1.0 \mathrm{~m}$ on a daily or weekly basis (Andersson et al. 2000). It seems inherently likely that root architecture of adult trees in the riparian zones will reflect at a large scale the variations exhibited by cutting roots in our greenhouse experiment. It is very difficult to verify the root architecture of adult trees in situ though there is emerging evidence that changing water levels from year to year strongly influence the response of floodplain trees to flow regime through their influence on root distribution (Shafroth et al. 2000; Andersen 2005). No significant differences in root length or weight were found between the two sexes 
in the greenhouse experiment suggesting that adopting different patterns of root architecture may not be used by the two sexes to co-exist in riparian spaces that otherwise appear similar.

\section{Sex ratios}

Our study of sex ratios on the regulated and free-flowing rivers showed little evidence of change away from the regional norm of a male to female ratio of 1:1.6 (0.62) for $S$. myrsinifolia-phylicifolia in the regulated Ume River suggesting that river regulation has not changed sex ratios. Additional information on sex ratios for this species is available from our study of SSS (Table 2) which again shows the two rivers to have very similar sex ratios but a stronger female bias (M/F ratio of 0.44 for Vindel River and M/F ratio of 0.45 for Ume River) than in the sex ratios study. In the greenhouse experiment, the fluctuating water table regime typical of a regulated river gave rise to significantly higher shoot and root biomass accumulation in than in the other treatments indicating that S. myrsinifolia-phylicifolia cuttings were not stressed by this departure from normal hydrological patterns during a single growing season. On the other hand, both shoot and root weights were significantly higher in cuttings from the Vindel River than in cuttings from the regulated Ume River. Interpreting this finding is not easy but it may reflect a lower resilience and reduced health in trees occupying a riparian zone that has been subjected to over 50 years of higher than average water tables through the growing season. In many regulated river systems, drought stress has been measured in members of the Salicaceae through, for example, increasing stomatal closure and xylem cavitation (Braatne et al. 1992; Tyree et al. 1994), reduced growth rates and (Willms et al. 1998), reduced sap-flow rates (Lambs and Muller 2002), branch and crown die-back and hydraulic partitioning within the tree (Stromberg and Patten 1991; Rood et al. 2003; Lambs et al. 2006). However, this literature has concentrated on members of the Populus genus in semi-arid river systems where these effects can be marked. In the Ume River system, in contrast, stress from water tables that remain constantly high during the growing season may be causing long-term reduction in the resilience of $S$. myrsinifolia-phylicifolia individuals though not, it would seem, through mechanisms that have, so far, caused a shift in sex ratios. This is in contrast to the findings of Braatne et al. (2007) along the Yakima River in Washington (US) who correlated male dominated sex ratios in young $P$. trichocarpa Torr. and A. Gray with changed flow patterns over a 30 year period since flow regulation. The changed flow regimes in their study altered recruitment patterns through either prolonged periods of bank-full stage during the growing season or scouring at lower elevations, especially disfavouring females. The picture is different for S. lapponum 
where the sex ratio was more strongly biased towards females in the regulated Ume River than in the free-flowing Vindel River though the sample size in the Ume River is limited.

\section{Impacts of changing hydrological regimes}

There are important differences in the winter water levels between the Vindel and Ume Rivers. In the Vindel River, water-levels drop to the annual lows during the winter season and Salix shrubs remain unaffected by ice, except for those in exposed parts of turbulent reaches where drifting ice floes may damage shrubs during spring floods. In the Ume River, on the other hand, water-levels remain high and fluctuating throughout the winter, the ice cover on the river moves up and down and erodes riparian shrubs that are easily removed. The resulting effect in the Ume River is that shrubs are confined to a narrower part of the riparian zone. We found a marked difference between the two rivers in the mean elevation of both sexes of S. myrsinifolia-phylicifolia. Thus, in the Vindel River the average elevation of females was $48.6 \mathrm{~cm}$ and that of males $46.8 \mathrm{~cm}$ higher than in the Ume River. Similarly the elevational range occupied by both sexes differed significantly between the two rivers (Table 2) with both sexes able to grow at considerably lower elevations in the Ume River (lowest elevations of $48.4 \mathrm{~cm}$ for females and $43.1 \mathrm{~cm}$ for males) compared with lowest elevations of $127.8 \mathrm{~cm}$ for females and $117.9 \mathrm{~cm}$ for males in the Vindel River. This is difficult to interpret in the light of the impact that changed flow regimes have had on the winter flows but a possible explanation may be found in terms of interspecific spatial segregation. Thus in the Ume River insufficient $S$. lapponum bushes were found to contribute to our data analyses but in the Vindel River this species was found to occupy a lower mean elevation band than S.myrsinifolia-phylicifolia (females mean elevation was $100.5 \mathrm{~cm}$, males mean elevation was $119.1 \mathrm{~cm}$ ). It is possible that because $S$. lapponum occupies lower elevation bands it has dropped out of the regulated Ume River system, due to winter scouring, reducing competition with S. myrsinifolia-phylicifolia.

Where different responses between the sexes to mesic or xeric substrate conditions have been measured in Salix species, female annual growth has been measured as $85 \%$ more than male growth in mesic sites but not in drier sites (S. glauca - Dudley 2006) and females also have higher levels of stomatal conductance in wetter conditions than males (S. arctica - Dawson and Bliss 1989). Our experimental data from cuttings showed that shoot weight was significantly different between the sexes (higher in females than males), and between some hydrological regimes (highest in the wettest regime), although the interaction between the two 
was not significant so we cannot say that females grew better in wetter sites than males, a finding which fits in with the absence of SSS found in the field.

\section{Regeneration niches and SSS}

We would suggest that a drawback of our studies and of many others that have sought evidence of SSS in Salix populations is that we are studying established willow populations and not newly regenerating populations. It might be more productive to search for niche dimensions at the time of establishment of individual trees to explain the distribution of sexes around a floodplain. It is well established that on many floodplains, regeneration is periodic and related to provision of very particular conditions of water availability and disturbance patterns during the first year of growth following germination. Thus, willows require open, well-watered but not waterlogged sites for successful regeneration; the seedlings must then not be subjected to physical disturbance by flooding or ice until they are well established (Johnson et al. 1976; Bradley and Smith 1986; Mahoney and Rood 1991; Hughes 1997). There are, however, huge drawbacks here as it is not possible to sex Salix seeds or seedlings and hence working experimentally with cuttings becomes an attractive alternative for understanding regeneration niches. Our data from the greenhouse experiment show differences between male and female growth patterns in response to different water table regimes and support the idea that regeneration niches (sensu Grubb 1977) might be critical in determining sex ratios in the adult population. Due to the inherently dynamic nature of riparian environments, the niche dimensions at the time of regeneration will change rapidly through time in response to geomorphological change and thus factors such as soil moisture and nutrients and elevation above or below a mean river stage level at the site of an adult willow could be very different to those at the time of establishment, confounding the relationship between location of a tree of a particular sex and the abiotic dimensions of its niche. In the field study, data were not collected on the ages of the sampled populations, but individuals can live for many decades. On the Ume River, all individuals are likely to have regenerated since dams were constructed and the positions of the riverbanks were altered about 50 years ago. This complication does not occur on the Vindel River.

The role of mycorrhizae has also not been considered in our study. Their role in riparian communities is not fully understood though there is some evidence from previous studies in nearby rivers in northern Sweden that levels of association of arbuscular mycorrhizal fungi in various herbaceous species are not related to soil moisture gradients and are not limited by 
water logging (M. Larsson and J. Persson unpubl.) when viewed across the width of the floodplain. In a recent study along a river in Montana, USA, Piotrowski et al. (2008) found a dominance of arbuscular mycorrhizal fungi during early successional stages in riparian zones and a dominance of ectomycorrhizal fungi during later stages (after around 20 years), especially in association with $P$. trichocarpa. However, they did not find significant correlations between these trends and soil variables including soil moisture but explain their findings in relation to abundance of host plants in different areas and flooding frequency in early successional stages. No investigations have been made into levels of mycorrhizal infection in male and female plants of dioecious species on floodplains but it is possible that they form part of the unstudied, underground niche dimensions that are likely to influence SSS, especially at the regeneration stage.

\section{Conclusion}

Dam construction has impacts that are clear in terms of measured changes to hydrological patterns but not so clear when the complex ecological responses of organisms to those changed hydrological patterns are considered over the long-term. Even well-designed experiments may not show relationships that are expected because of confounding factors that have not been measured, or more often, that are neither measurable nor easy to define. Our work using male and female cuttings from members of the dioecious Salicaceae family has shown some differences between growth responses between the sexes to a variety of hydrological and sedimentological conditions (Hughes et al. 2001 and this article). The Salicaceae are very important components of many riparian ecosystems across all major biomes. They occupy early successional niches in many riparian woodland types and in others are the only family present in the shrub or tree layers. Because it is not possible to sex seedlings, experimental work to investigate the response of the two sexes to environmental factors can only be carried out with cuttings taken from adult individuals whose sex is known. However, there are drawbacks with the use of cuttings as they are unlikely to behave in the same way as seedlings and so experimental data from a greenhouse cannot always readily be used to help interpret findings in the field. Tagging seedlings in the field and following their development over decadal time frames is probably the only convincing way of unravelling the effects that long-term hydrological change will have on sex ratios in riparian zones. It is recognised that riparian vegetation could play a critical role in the mitigation of climate change impacts (Palmer et al. 2008) and it is likely that this role will be influenced by the complex interplay between hydrology and sex ratios in riparian zones. 


\section{Acknowledgements}

We thank Ian Lawson for constructing rhizopods, Anna McCann and Phil Hughes for measurements made on soils and roots in Cambridge, and Chris Rolfe and Steve Boreham for work on soil analyses. We also thank the late Jeff Braatne, University of Idaho, USA, for advice on preparation of cuttings. Financial support was provided by the European Commission Environment Programme under Contract No. EVK1-CT-1999-0031. The authors are grateful to Dr. H. Barth of the European Commission for his interest in this project. Very perceptive comments were received from two anonymous reviewers and from Stewart Rood, University of Lethbridge, Canada and these have greatly enhanced the manuscript. This article is dedicated to the memory of Jeff Braatne. 


\section{References}

Alliende MC, Harper JL (1989) Demographic studies of a dioecious tree I. Colonization, sex and age structure of a population of Salix cinerea. J. Ecol. 77:1029-1047

Alström-Rapaport C, Lascoux M, Gullberg U (1997) Sex determination and sex ratio in the dioecious shrub Salix viminalis L. Theor. Appl. Genet. 94:493-497

Alström-Rapaport C, Lascoux M, Wang YC et al. (1997) Identification of a RAPD marker linked to sex determination in the basket willow (Salix viminalis L.). J. Hered. 89:44-49

Andersen DC (2005) Characterizing flow regimes for floodplain forest conservation: an assessment of factors affecting sapling growth and survivorship on three cold desert rivers.

Can. J. For. Res. 35:2886-2899

Andersson E, Nilsson C, Johansson M (2000) Effects of river fragmentation on plant dispersal and riparian flora. Reg. Rivers: Res. Manage. 16:83-89

Barsoum N (2002) Relative contributions of sexual and asexual regeneration strategies in Populus nigra and Salix alba during the first years of establishment on a braided gravel bed river. Evol. Ecol. 15:255-279

Barsoum N, Hughes FMR (1998) Regeneration response of Black Poplar to changing river levels. In: Wheatear H, Kirkby C (eds) Hydrology in a changing environment, Volume 1, British Hydrological Society and Wiley, Chichester, pp 397-412

Bierzychudek P, Eckhart V (1988) Spatial segregation of the sexes of dioecious plants. Am. Nat. 132:43-53

Braatne JH, Hinckley TM, Stettler RF (1992) Influence of soil water on the physiological and morphological components of plant water balance in Populus trichocarpa and Populus deltoides and their $\mathrm{F}_{1}$ hybrids. Tree Physiol. 11:325-339

Braatne JH, Jamieson R, Gill K et al. (2007) Instream flows and the decline of riparian cottonwoods along the Yakima River, Washington, USA. River Res. Appl. 23:247-267

Bradley CE, Smith DG (1986) Plains cottonwood recruitment and survival on a prairie meandering river floodplain, Milk River, southern Alberta and northern Montana. Can. J. Bot. 64:1433-1442

Comtois P, Simon JP, Payette S (1986) Clonal distribution and sex ratio in northern populations of balsam poplar, Populus balsamifera. Holarct. Ecol. 9:251-260

Danell K, Elmqvist T, Ericson L, Salomonson A (1985) Sexuality in willows and preference by bark-eating voles: defence or not? Oikos 44:82-90

Dawson TE, Bliss LC (1989) Patterns of water use and the tissue water relations in the dioecious shrub, Salix arctica: the physiological basis for habitat partitioning between the sexes. Oecologia 79:332-343 
De Jong TJ, Van Batenburg FHD, Van Dijk J (2002) Seed sex ratio in dioecious plants depends on relative dispersal of pollen and seeds: an example using a chessboard simulation model. J. Evol. Biol. 15:373-379

Dormann CF, Skarpe C (2002) Flowering, growth and defence in the two sexes: consequences of herbivore exclusion for Salix polaris. Funct. Ecol. 16:649-656

Dudley LS (2006) Ecological correlates of secondary sexual dimorphism in Salix glauca (Salicaceae). Am. J. Bot. 93:1775-1783

Dynesius M, Nilsson C (1994) Fragmentation and flow regulation of river systems in the northern third of the world. Science 266:753-762

Elmqvist T, Ericson L, Danell K. et al. (1988) Latitudinal sex ratio variation in willows, Salix spp., and gradients in vole herbivory. Oikos 51:259-266

Falinski JB (1980) Vegetation dynamics and sex structure of the populations of pioneer dioecious woody plants. Vegetatio 43:23-38

Falinski JB (1998) Androgyny of individuals and polygamy in populations of Salix myrsinifolia Salisb. in the south-western part of its range (NE-Poland). Perspect. Plant Ecol. $1 / 2: 238-266$

Francis RA, Gurnell AM, Petts GE et al. (2005) Survival and growth responses of Populus nigra, Salix eleagnos and Alnus incana cuttings to varying levels of hydric stress. For. Ecol. Manage. 210:291-301

Gamache I, Houle G (1997) Spatial structure of a dioecious shrub population, Salix planifolia, along a successional gradient in a subarctic dune. Am. J. Bot. 84:99-100

Grafen A, Hails R (2002) Modern statistics for the life sciences. Oxford University Press, Oxford

Grubb PJ (1977) The maintenance of species-richness in plant communities: the importance of the regeneration niche. Biol. Rev. Camb. Phil. Soc. 52:107-145

Gurnell AM, Thompson K, Goodson J et al. (2008) Propagule deposition along river margins: linking hydrology and ecology. J. Ecol. 96:553-565

Hughes FMR (1990) The influence of flooding regimes on forest distribution and composition in the Tana floodplain, Kenya. J. Appl. Ecol. 27: 475-492

Hughes FMR (1997) Floodplain biogeomorphology. Prog. Phys. Geog. 21:501-529

Hughes FMR, Harris T, Richards KS et al. (1997) Woody riparian species response to different soil moisture conditions: laboratory experiments on Alnus incana (L.) Moench. Glob. Ecol. Biogeog. Lett. 6:247-256

Hughes FMR, Barsoum N, Richards KS et al. (2000) The response of male and female black poplar (Populus nigra L. subspecies betulifolia (Pursh) W. Wettst.) cuttings to different water 
table depths and sediment types: implications for flow management and river corridor biodiversity. Hydrol. Process. 14:3075-3098

Hultine KR, Bush SE, West AG et al. (2007a) The effect of gender on sap flux-scaled transpiration in a dominant riparian tree species: box elder (Acer negundo). J. Geophys. Res. 112, G03S06 doi: 10.1029/2006 JG000232

Hultine KR, Bush SE, West AG et al. (2007b) Population structure, physiology and ecohydrological impacts of dioecious riparian tree species of western North America. Oecologia 154:85-93

Imbert E, Lefèvre F (2003) Dispersal and gene flow of Populus nigra (Salicaceae) along a dynamic river system. J. Ecol. 91:447-456

Jansson R, Nilsson C, Dynesius M et al. (2000) Effects of river regulation on river-margin vegetation: a comparison of eight boreal rivers. Ecol. Appl. 10: 203-224

Johansson ME, Nilsson C, Nilsson E (1996) Do river function as corridors for plant dispersal? J. Veg. Sci. 7:593-598

Johnson WC, Burgess RL, Keammerer WR (1996) Forest overstorey vegetation and environment on the Missouri River floodplain in North Dakota. Ecol. Monogr. 46:59-84

Kaul RB, Kaul MN (1984) Sex ratios of Populus deltoides and Salix amygdaloides (Salicaceae). Southwest. Nat. 29:265-269

Lambs L, Muller E (2002) Sap flow and water transfer in the Garonne River riparian woodland, France: first results on poplar and willow. Ann. For. Sci. 58:301-315

Lambs L, Loubiat M, Girel J et al. (2006) Survival and acclimatation of Populus nigra to drier conditions after damming of an alpine river, southeast France. Ann. For. Sci. 63:377385

Leigh A, Nicotra AB (2003) Sexual dimorphism in reproductive allocation and water use efficiency in Maireana pyramidata (Chenopodiaceae), a dioecious, semi-arid shrub. Aust. J. Bot. 51:509-514

Letts MG, Phelan CA, Johnson DRE et al. (2008) Seasonal photosynthetic gas exchange and leaf reflectance characteristics of male and female cottonwoods in a riparian woodland. Tree Physiol. 28:1037-1048

Mahoney JM, Rood SB (1991) A device for studying the influence of declining water table on poplar growth and survival. Tree Physiol. 8:305-314

Mahoney JM, Rood SB (1992) Response of a hybrid poplar to water table decline in different substrates. For. Ecol. Manage. 54:141-156

Nichols-Orians CM, Fritz RS, Clausen TP (1993) The genetic basis for variation in the concentration of phenolic glycosides in Salix sericea: clonal variation and sex-based differences. Biochem. Syst. Ecol. 21:535-542 
Niesenbaum RA (1992) Sex ratio, components of reproduction, and pollen deposition in Lindera benzoin (Lauraceae). Am. J. Bot. 79:495-500

Nilsson C, Ekblad A, Gardfjell M et al. (1991) Long-term effects of river regulation on river margin vegetation. J. Appl. Ecol. 28:963-987

Onyekwelu SS, Harper JL (1979) Sex ratio and niche differentiation in spinach (Spinachia oleracea L.). Nature 282:609-611

Palmer MA, Reidy-Liermann CA, Nilsson C et al. (2008) Climate change and the world's river basins: anticipating management options. Front. Ecol. Environ. 6:81-89

Piotrowski JS, Lekberg Y, Harner MJ et al. (2008) Dynamics of mycorrhizae during development of riparian forests along an unregulated river. Ecography 31:245-253

Rice WR (1989) Analyzing tables of statistical tests. Evolution 43:223-225

Rood SB, Braatne JH, Hughes FMR (2003) Ecophysiology of riparian cottonwoods: streamflow dependency, water relations and restoration. Tree Physiol. 23:1113-1124

Rood SB, Nielsen JL, Shenton L, Gill KM, Letts MG (in press) Effects of flooding on leaf development, photosynthesis and water-use efficiency in narrowleaf cottonwood, a willowlike poplar. Photosynthesis Res.

Rowland DL, Johnson, NC (2001) Sexual demographics of riparian populations of populus deltoids: Can mortality be predicted from a change in reproductive status? Can. J. Bot. 79:702-710

Segelquist CA, Scott ML, Auble GT (1993) Establishment of Populus deltoides under simulated alluvial groundwater declines. Am. Midl. Nat. 130:274-285

Semerikov V, Lagercrantz U, Tsarouhas V et al. (2003) Genetic mapping of sex-linked markers in Salix viminalis L. Heredity 91:293-299

Shafroth PB, Scott ML, Friedman JM et al. (1994) Establishment, sex structure and breeding system of an exotic riparian willow, Salix $\times$ rubens. Am. Midl. Nat. 132:159-172

Shafroth PB, Stromberg JC, Patten DT (2000) Woody riparian vegetation response to different alluvial water table regimes. West. N.A. Nat. 60:66-76

Stromberg J C, Patten DT (1991) Instream flow requirements for cottonwoods at Bishop Creek, Inyo County, California. Rivers 2:1-11

Tabbush P (1996) Native poplars and the restoration of floodplain forests. Q. J. For. 90:128134

Turcotte J, Houle G (1997) Resource allocation in the dioecious shrub, Salix planifolia Pursh, subarctic Quebec. Am. J. Bot. 84:109-110 
Tyree MT, Kolb KJ, Rood SB et al. (1994) Vulnerability to drought-induced cavitation of riparian cottonwoods in Alberta: a possible factor in the decline of the ecosystem? Tree Physiol. 14:455-466

Ueno N, Kanno H, Seiwa K (2006) Sexual differences in shoot and leaf dynamics in the dioecious tree Salix sachalinensis. Can. J. Bot. 84:1852-1859

Ueno N, Suyama Y, Seiwa K (2007) What makes the sex ratio female-biased in the dioecious tree Salix sachalinensis? J. Ecol. 95:951-959

Ward JK, Dawson TE, Ehleringer JR (2002) Responses of Acer negundo genders to interannual differences in water availability determined from carbon isotope ratios of tree ring cellulose. Tree Physiol. 22:339-346

Waser NM (1984) Sex ratio variation in populations of a dioecious desert perennial, Sommondsia chinensis. Oikos 42:343-348

Willms J, Rood SB, Willms W et al. (1998) Branch growth of riparian cottonwoods: a hydrologically sensitive dendrochronological tool. Trees 12:215-223

Willson M (1983) Plant reproductive ecology. Wiley, Chichester

Xu X, Peng G, Wu C et al. (2008) Drought inhibits photosynthetic capacity more in females than in males of Populus cathayana. Tree Physiol. 28:1751-1759 
Table 1 Hydrological regimes (treatments) used in four pairs of rhizopods.

\begin{tabular}{|c|c|c|}
\hline $\begin{array}{l}\text { Hydrological } \\
\text { regime } \\
\text { number }\end{array}$ & Hydrological regime description & $\begin{array}{l}\text { Notes on hydrological } \\
\text { regimes }\end{array}$ \\
\hline 1 & $\begin{array}{l}2 \mathrm{~cm} \text { drawdown/day }+ \text { mimicked } \\
\text { weekly rainfall event ( } 5 \mathrm{~mm} \text { depth) }\end{array}$ & $\begin{array}{l}\text { Typical of lower elevations } \\
\text { in the riparian zone during } \\
\text { the main growing season } \\
\text { on the free-flowing Vindel } \\
\text { River }\end{array}$ \\
\hline 2 & $\begin{array}{l}\text { 4-day fluctuating water table } \\
\text { consisting of } 1 \text { day with the water } \\
\text { table at the soil surface and } 3 \text { days } \\
\text { with the whole rhizopod emptied of } \\
\text { water }+ \text { mimicked weekly rainfall } \\
\text { event ( } 5 \mathrm{~mm} \text { depth) }\end{array}$ & $\begin{array}{l}\text { Typical of regimes } \\
\text { experienced on the } \\
\text { regulated Ume River } \\
\text { during the growing season }\end{array}$ \\
\hline 3 & $\begin{array}{l}10 \mathrm{~cm} \text { drawdown per day }+ \\
\text { mimicked weekly rainfall event ( } 5 \\
\text { mm depth) }\end{array}$ & $\begin{array}{l}\text { Typical of higher } \\
\text { elevations in the riparian } \\
\text { zone following spring melt } \\
\text { floods on the free-flowing } \\
\text { Vindel River }\end{array}$ \\
\hline 4 & $\begin{array}{l}10 \mathrm{~cm} \text { drawdown per day for } 7 \\
\text { days followed by } 3 \mathrm{~cm} \text { drawdown } \\
\text { per day }+ \text { mimicked weekly rainfall } \\
\text { event ( } 5 \mathrm{~mm} \text { depth) }\end{array}$ & $\begin{array}{l}\text { Typical of middle level } \\
\text { elevations following spring } \\
\text { melt floods on the free- } \\
\text { flowing Vindel River }\end{array}$ \\
\hline
\end{tabular}


Table 2 Spatial segregation of sexes in Salix myrsinifolia-phylicifolia along transects in the Vindel and Ume Rivers. Ratios are based on sexed individuals. Bold face denotes $P$-values $<0.05$

\begin{tabular}{|c|c|c|c|c|c|c|c|}
\hline \multirow[t]{2}{*}{$\begin{array}{l}\text { Transect } \\
\text { number }\end{array}$} & \multirow[t]{2}{*}{ Transect location } & \multirow[t]{2}{*}{ Ratio M/F } & \multirow[t]{2}{*}{$N_{\text {sexed }}$} & \multirow[t]{2}{*}{$N_{\text {total }}$} & \multicolumn{2}{|c|}{$\begin{array}{l}\text { Mean elevation } \\
\left.\text { (cm above } w_{\text {mean }}\right)\end{array}$} & \multirow{2}{*}{$\begin{array}{c}\begin{array}{c}\text { Difference in } \\
\text { elevation } \\
\text { F vs. M }\end{array} \\
P\end{array}$} \\
\hline & & & & & Females & Males & \\
\hline \multicolumn{8}{|l|}{ Vindel River } \\
\hline V1 & Bjursele E & 0.32 & 25 & 65 & 143.3 & 142.3 & 0.875 \\
\hline V2 & Bjursele W & 0.62 & 63 & 76 & 169.1 & 185.4 & $0.036^{*}$ \\
\hline V3 & Bäckarforsen & 0.13 & 17 & 52 & 170.9 & 158.5 & 0.250 \\
\hline V4 & Strycksele & 0.56 & 56 & 61 & 127.8 & 117.9 & 0.686 \\
\hline V5 & Sirapsbacken & 0.61 & 45 & 62 & 146.4 & 166.5 & $0.015^{*}$ \\
\hline All transects & & 0.45 & 206 & 316 & 151.5 & 154.1 & \\
\hline \multicolumn{8}{|l|}{ Ume River } \\
\hline U1 & Rusfors & 0.44 & 62 & 71 & 51.3 & 43.1 & 0.447 \\
\hline U2 & Tuggen & 0.77 & 53 & 61 & 130.8 & 123.7 & 0.816 \\
\hline U3 & Bjurfors & 0.50 & 51 & 107 & 48.4 & 103.8 & 0.059 \\
\hline U4 & Pengfors & 0.21 & 68 & 75 & 81.1 & 74.4 & 0.622 \\
\hline U5 & Sörfors W & 0.47 & 50 & 69 & 162.0 & 127.3 & 0.107 \\
\hline U6 & Sörfors E & 0.22 & 50 & 59 & 144.0 & 171.2 & 0.158 \\
\hline All transects & & 0.44 & 334 & 442 & 102.9 & 107.3 & \\
\hline
\end{tabular}

* Not significant 'table wide' with sequential Bonferroni correction. 
Table 3 Spatial segregation of sexes in Salix lapponum along transects in the Vindel River. Ratios are based on sexed individuals. Bold face denotes $P$-values $<0.05$. Salix lapponum in the Ume River was absent from most transects and has not been included.

\begin{tabular}{|c|c|c|c|c|c|c|c|}
\hline \multirow[t]{2}{*}{$\begin{array}{c}\text { Transect } \\
\text { Vindel River }\end{array}$} & & \multirow[t]{2}{*}{ Ratio M/F } & \multirow[t]{2}{*}{$N_{\text {sexed }}$} & \multirow[t]{2}{*}{$N_{\text {total }}$} & \multicolumn{2}{|c|}{$\begin{array}{l}\text { Mean elevation } \\
\left(\mathrm{cm} \text { above } w_{\text {mean }}\right)\end{array}$} & \multirow{2}{*}{$\begin{array}{c}\begin{array}{c}\text { Difference in } \\
\text { elevation } \\
\text { F vs. M }\end{array} \\
P\end{array}$} \\
\hline & & & & & Females & Males & \\
\hline V1 & Bjursele E & 0.16 & 43 & 65 & 91.5 & 89.0 & 0.636 \\
\hline V2 & Bjursele W & 0.26 & 43 & 48 & 141.1 & 133.0 & 0.180 \\
\hline V3 & Bäckarforsen & 0.10 & 32 & 45 & 139.5 & 166.7 & 0.519 \\
\hline V4 & Strycksele & 0.48 & 46 & 51 & 27.5 & 94.8 & $0.047^{*}$ \\
\hline V5 & Sirapsbacken & 0.87 & 56 & 63 & 102.7 & 112.2 & 0.290 \\
\hline All transects & & 0.37 & 220 & 272 & 100.5 & 119.1 & \\
\hline
\end{tabular}

*Not significant 'table wide' with sequential Bonferroni correction. 
Table 4 Sex ratios found for Salix myrsinifolia-phylicifolia in the studied rivers. Bold face denotes significantly different from $1: 1$ ratio $\left(X^{2}\right.$ test; $P$-values $\left.<0.05\right)$

\begin{tabular}{rccc}
\multicolumn{2}{l}{ Vindel River } \\
\hline Locality & $\begin{array}{c}\text { Number of } \\
\text { females }\end{array}$ & $\begin{array}{c}\text { Number of } \\
\text { males }\end{array}$ & $\begin{array}{c}\text { Ratio } \\
\text { M/F }\end{array}$ \\
\hline Vindel 1 & 36 & 18 & $\mathbf{0 . 5 0}$ \\
2 & 39 & 24 & 0.62 \\
3 & 36 & 20 & $\mathbf{0 . 5 6}$ \\
4 & 42 & 24 & $\mathbf{0 . 5 7}$ \\
5 & 30 & 22 & 0.73 \\
6 & 30 & 20 & 0.67 \\
7 & 30 & 24 & 0.80 \\
8 & 38 & 12 & $\mathbf{0 . 3 2}$ \\
9 & 34 & 16 & $\mathbf{0 . 4 7}$ \\
10 & 26 & 24 & 0.92 \\
11 & 28 & 17 & 0.61 \\
12 & 19 & 6 & $\mathbf{0 . 3 2}$
\end{tabular}

\begin{tabular}{rccc}
\multicolumn{3}{l}{ Ume River } \\
\hline Locality & $\begin{array}{c}\text { Number of } \\
\text { females }\end{array}$ & $\begin{array}{c}\text { Number of } \\
\text { males }\end{array}$ & $\begin{array}{c}\text { Ratio } \\
\text { M/F }\end{array}$ \\
\hline Ume 1 & 17 & 15 & 0.88 \\
2 & 27 & 23 & 0.85 \\
3 & 30 & 18 & 0.60 \\
4 & 28 & 22 & 0.79 \\
5 & 32 & 18 & $\mathbf{0 . 5 6}$ \\
6 & 35 & 15 & $\mathbf{0 . 4 3}$ \\
7 & 27 & 23 & 0.85 \\
8 & 28 & 22 & 0.79 \\
9 & 33 & 17 & $\mathbf{0 . 5 2}$ \\
10 & 33 & 17 & $\mathbf{0 . 5 2}$ \\
11 & 38 & 12 & $\mathbf{0 . 3 2}$ \\
12 & 38 & 16 & $\mathbf{0 . 4 2}$ \\
13 & 28 & 21 & 0.75 \\
14 & 29 & 21 & 0.72 \\
15 & 30 & 20 & 0.67 \\
16 & 39 & 11 & $\mathbf{0 . 2 8}$ \\
17 & 31 & 19 & 0.61 \\
\hline Mean & & & $\mathbf{0 . 6 2}$ \\
\hline
\end{tabular}


Table 5 Sex ratios found for Salix lapponum in the studied rivers. Bold face denotes significantly different from $1: 1$ ratio $\left(X^{2}\right.$ test; $P$-values $\left.<0.05\right)$

Vindel River

\begin{tabular}{rccc}
\hline Locality & $\begin{array}{c}\text { Number of } \\
\text { females }\end{array}$ & $\begin{array}{c}\text { Number of } \\
\text { males }\end{array}$ & $\begin{array}{c}\text { Ratio } \\
\text { M/F }\end{array}$ \\
\hline Vindel 1 & 23 & 29 & 1.26 \\
2 & 45 & 6 & $\mathbf{0 . 1 3}$ \\
3 & 31 & 17 & $\mathbf{0 . 5 5}$ \\
11 & 30 & 26 & 0.87 \\
12 & 37 & 6 & $\mathbf{0 . 1 6}$ \\
13 & 29 & 3 & $\mathbf{0 . 1 0}$ \\
\hline Mean & & & $\mathbf{0 . 5 1}$ \\
\hline
\end{tabular}

\section{Ume River}

\begin{tabular}{rccc}
\hline Locality & $\begin{array}{c}\text { Number of } \\
\text { females }\end{array}$ & $\begin{array}{c}\text { Number of } \\
\text { males }\end{array}$ & $\begin{array}{c}\text { Ratio } \\
\mathrm{M} / \mathrm{F}\end{array}$ \\
\hline Ume 14 & 37 & 13 & $\mathbf{0 . 3 5}$ \\
17 & 38 & 12 & $\mathbf{0 . 3 2}$
\end{tabular}


Table 6 Results of analysis of variance on growth of Salix myrsinifolia-phylicifolia in the greenhouse experiment. Bold face denotes $P$-values $<0.05$.

\begin{tabular}{|c|c|c|c|c|c|c|c|c|c|}
\hline & \multicolumn{3}{|c|}{ Shoot Weight } & \multicolumn{3}{|c|}{ Root Weight* } & \multicolumn{3}{|c|}{ Root Length* } \\
\hline & df & $\mathrm{F}$ & $\mathrm{P}$ & df & $\mathrm{F}$ & $\mathrm{P}$ & df & $\mathrm{F}$ & $\mathrm{P}$ \\
\hline CUTTING DIAMETER & 1 & 11.68 & 0.00 & 1 & 8.05 & 0.01 & 1 & 0.40 & 0.53 \\
\hline RIVER & 1 & 8.94 & 0.00 & 1 & 10.05 & 0.00 & 1 & 2.65 & 0.11 \\
\hline REGIME (treatment) & 3 & 14.26 & 0.00 & 3 & 4.97 & 0.00 & 3 & 8.30 & 0.00 \\
\hline SEX & 1 & 5.26 & 0.02 & 1 & 0.14 & 0.71 & 1 & 0.34 & 0.56 \\
\hline RIVER * REGIME & 3 & 0.36 & 0.78 & 3 & 0.42 & 0.74 & 3 & 0.31 & 0.82 \\
\hline RIVER * SEX & 1 & 0.97 & 0.39 & 1 & 0.31 & 0.58 & 1 & 0.15 & 0.70 \\
\hline REGIME * SEX & 3 & 0.92 & 0.44 & 3 & 0.54 & 0.66 & 3 & 0.32 & 0.81 \\
\hline Error & 94 & & & 89 & & & 89 & & \\
\hline Total & 108 & & & 103 & & & 103 & & \\
\hline
\end{tabular}

* 5 samples across the experiment were incompletely extracted from soil cores and removed from the analyses. 
Table 7 Root and shoot weights and root lengths (mean $\pm \mathrm{SE}^{*}$ ) of cuttings in the different hydrological regimes

\begin{tabular}{|c|c|c|c|c|}
\hline & \multicolumn{4}{|c|}{ Hydrological regime } \\
\hline & $\begin{array}{c}1 \\
(2 \mathrm{~cm} / \text { day } \\
\text { drawdown) } \\
n=25 \text { (roots) } \\
n=29 \text { (shoots) }\end{array}$ & $\begin{array}{c}2 \\
\text { (3 days } \\
\text { drawdown and } 1 \\
\text { day flooded) } \\
n=26 \text { (roots and } \\
\text { shoots) }\end{array}$ & $\begin{array}{c}3 \\
\text { (10 cm/day } \\
\text { drawdown) } \\
n=26 \text { (roots) } \\
n=27 \text { (shoots) }\end{array}$ & $\begin{array}{c}4 \\
(10+3 \mathrm{~cm} / \text { day } \\
\text { drawdown) } \\
n=26 \text { (roots and } \\
\text { shoots) }\end{array}$ \\
\hline Shoot weight (g) & $0.59 \pm 0.07 a$ & $1.09 \pm 0.12$ & $0.50 \pm 0.05 a$ & $0.66 \pm 0.05 a$ \\
\hline Root weight (g) & $1.85 \pm 0.20 \mathrm{ab}$ & $2.25 \pm 0.23 a$ & $1.29 \pm 0.17 c$ & $1.46 \pm 0.13 b c$ \\
\hline Root length (mm) & $121.44 \pm 5.08 a$ & $84.15 \pm 5.06$ & $99.12 \pm 5.86 b$ & $104.04 \pm 4.86 b$ \\
\hline
\end{tabular}

* Different letters between columns in each row indicate significant differences between regimes (LSD post hoc tests in GLM; $P<0.05$ ) 
Table 8 Root and shoot weights and root lengths (mean $\pm \mathrm{SE}^{*}$ ) of cuttings from the different rivers of origin

\begin{tabular}{lcc}
\hline & Vindel River & Ume River \\
$n=64$ (shoots) & $n=44$ (shoots) \\
& $n=61$ (roots) & $n=42$ (roots) \\
\hline Shoot weight $(\mathrm{g})^{*}$ & $0.80 \pm 0.06$ & $0.56 \pm 0.06$ \\
Root weight $(\mathrm{g})^{*}$ & $1.95 \pm 0.13$ & $1.35 \pm 0.13$ \\
Root length $(\mathrm{mm})$ & $105.90 \pm 3.71$ & $96.33 \pm 4.13$
\end{tabular}

* indicates significant difference according to GLM 
Table 9 Root and shoot weights and root lengths (mean $\pm \mathrm{SE}^{*}$ ) of female and male cuttings

\begin{tabular}{lcc}
\hline & $\begin{array}{c}\text { Female } \\
n=54 \text { (shoots and roots) }\end{array}$ & $\begin{array}{c}\text { Male } \\
n=54 \text { (shoots) } \\
n=49 \text { (roots) }\end{array}$ \\
\hline Shoot weight $(\mathrm{g})^{*}$ & $0.84 \pm 0.06$ & $0.57 \pm 0.05$ \\
Root weight $(\mathrm{g})$ & $1.87 \pm 0.13$ & $1.53 \pm 0.14$ \\
Root length $(\mathrm{mm})$ & $105.36 \pm 3.94$ & $98.31 \pm 3.93$ \\
& & \\
\hline * indicates significant difference according to GLM
\end{tabular}




\section{Figure Legends}

Fig. 1 Map showing field sites along the Vindel and Ume Rivers, northern Sweden. Site numbers refer to those in Tables 2 and 3

Fig. 2 Average root weight at $10 \mathrm{~cm}$ depth increments across the four hydrological regimes

Fig. 3 Results from the continuous monitoring of soil suction/pressure (hPa) using tensiometers at depths of $0.3 \mathrm{~m}$ and $1.0 \mathrm{~m}$ within a growth tube from each of the four experimental hydrological regimes (a) Regime 1- water table drawn down by $2 \mathrm{~cm} /$ day + weekly rainfall event (b) Regime 2fluctuating water table on a 4-day cycle + weekly rainfall event (c) Regime 3- water table drawn down by $10 \mathrm{~cm} /$ day + weekly rainfall event (d) Regime 4- water table drawn down by $10 \mathrm{~cm} /$ day for 7 days followed by $3 \mathrm{~cm} /$ day + weekly rainfall event. 


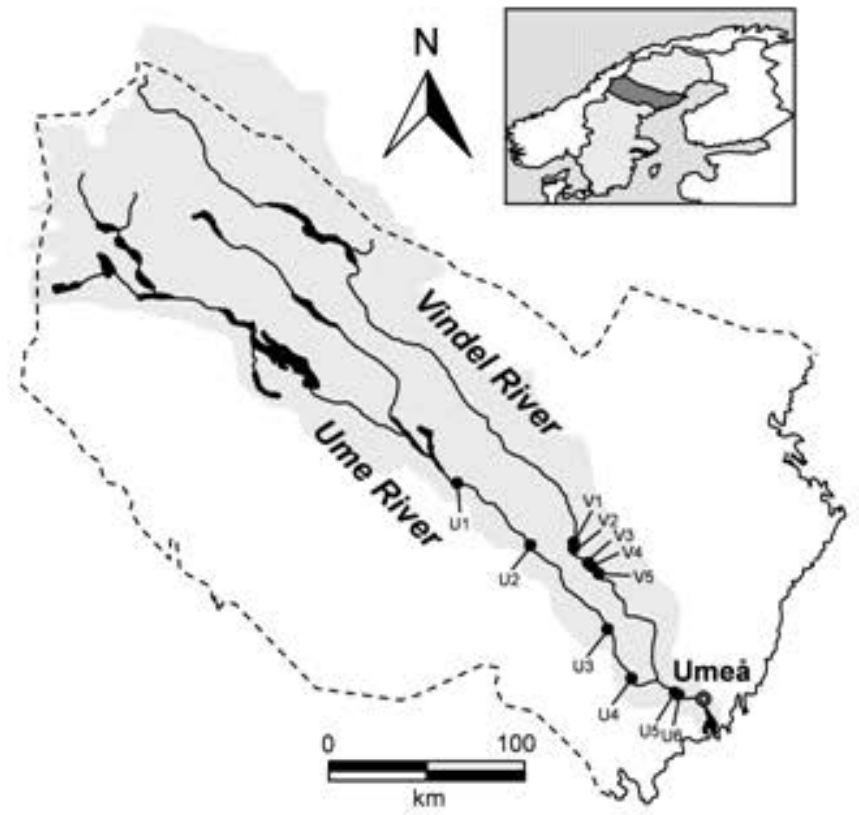




\section{Figure 2}

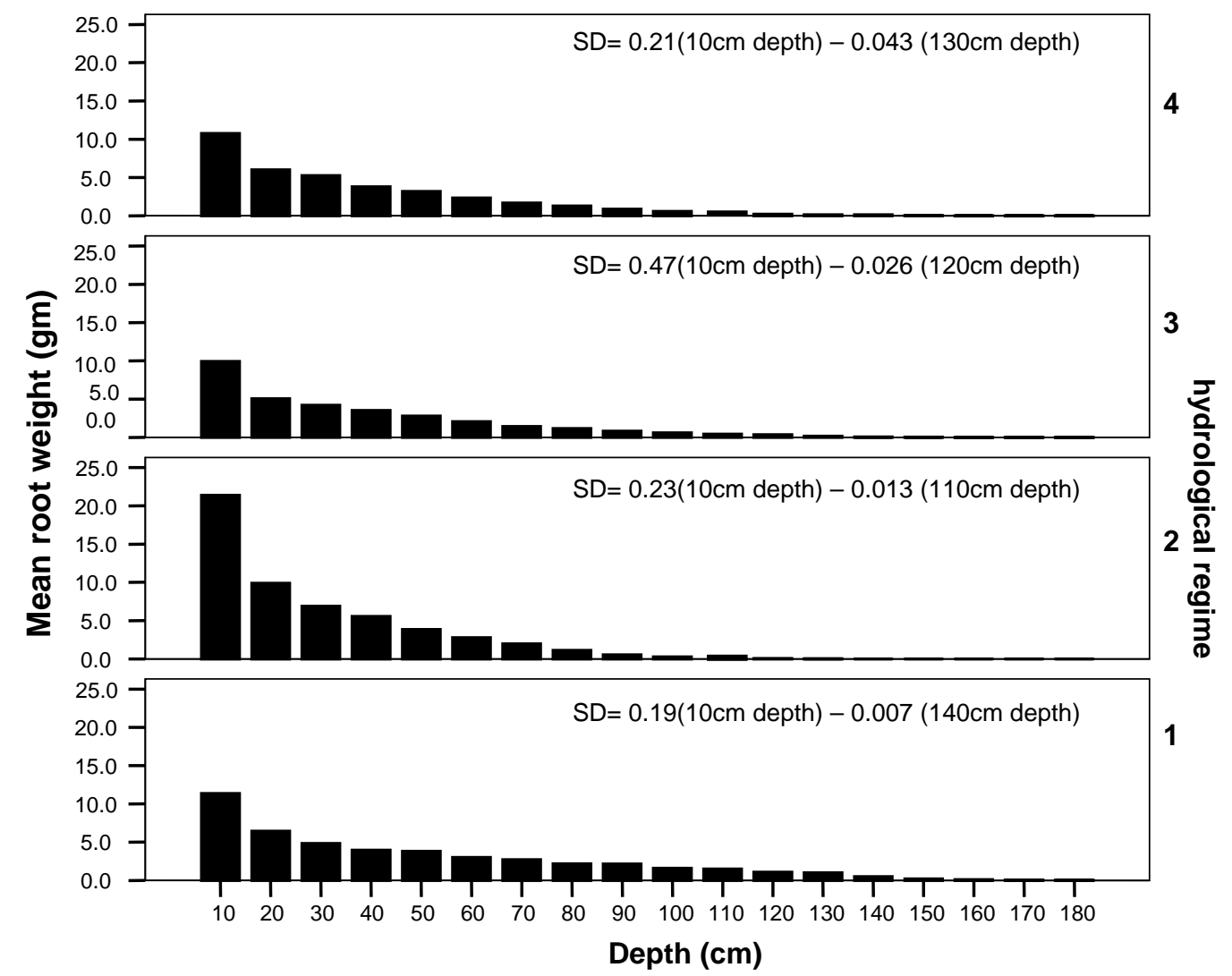


